\title{
STORYING AN INTERCONNECTED WEB OF RELATIONSHIPS IN INDIGENOUS LANGUAGE RECLAMATION WORK AND SCHOLARSHIP
}

\author{
Kari A. B. Chew ${ }^{1}$ \\ University of Oklahoma \\ Sheilah E. Nicholas \\ University of Arizona \\ Candace K. Galla \\ University of British Columbia \\ Keiki Kawai'ae'a \\ University of Hawai'i at Hilo \\ Wesley Y. Leonard \\ University of California, Riverside \\ Wilson de Lima Silva \\ University of Arizona
}

\begin{abstract}
Indigenous language work is manifested in a diversity of community-led responses of resilience and persistence. Indigenous persons who are reclaiming their languages have entered academia with goals of contributing to community language reclamation efforts and broader resurgence movements. Adapting Archibald's (2008) concept of storyworkexperiential narratives that privilege a cultural lens-we take a dialogic approach for scholar-educators to story their Indigenous language work within a web of interrelated relationships. From our positionalities as Chikashsha, Hopisino, Kanaka Hawai'i, myaamia, and Brazilian scholars, we ask and reflect on the following questions: Who are we storying with and for? What does language work look like in our community contexts and academic collaborations? How do we define cultural praxis in our work? What principles inform and emerge from our collective work? How do we co-construct knowledge that will sustain our language work and relationships? This reflective and reflexive process engages and maintains a continual balance of the cumulative past and present toward the future. Foremost, we aspire to act and work consistently in ways that are good for our peoples and communities, which includes a view of the research we undertake as purposeful journeying (Hill \& Wilkinson, 2014) within our academic contexts and scholarship.
\end{abstract}

${ }^{1}$ Correspondence: Kari A. B. Chew, University of Oklahoma, kchew@ou.edu 
Keywords: language reclamation, storywork, Indigenous communities, academic collaborations, Indigenous identity

Citation: Chew, K. A. B., Nicholas, S. E., Galla, C. K., Kawai'ae'a, K., Leonard, W. Y., \& Silva, W. D. L. (2021). Storying an interconnected web of relationships in Indigenous language reclamation work and scholarship. WINHEC: International Journal of Indigenous Education Scholarship, 16(1), 334-375. http://dx.doi.org/10.18357/wj1202120291. Special Issue on Indigenous Language Revitalization: Innovation, Reflection and Future Directions, Guest CoEditors Drs. Onowa McIvor and Kari A. B. Chew. 


\section{Prologue}

We come together through a shared responsibility to Indigenous language work. There is no single story that brings our paths together; rather, our stories intersect at various times and places, forming a web of relationships. As individuals, our paths have intersected at various convenings, including the American Indian Language Development Institute (AILDI) at the University of Arizona and Natives4Linguistics at the Linguistic Society of America annual meetings. We planned to come together as a group for the first time at a colloquium organized by Nicholas and Chew, called Braided histories, braided futures of Indigenous language reclamation work: Retelling ancestral stories, storying new Indigenous linguistic futures, at the American Association for Applied Linguistics 2020 meeting. Due to the pandemic-related cancellation of this event, this article provides an alternative venue for us to bring to fruition our vision of a dialogic approach to storying our individual and collective language work. We begin by introducing ourselves and inviting the reader into dialogue with us.

Chokma, saholhchifoat Kari Chew. Chikashsha saya. Amanompa' ithanali. Greetings, my name is Kari Chew. I am a Chickasaw Nation citizen. I am learning my language. My work as an assistant professor of Indigenous education supports language education work, especially for adult and diasporic language learners.

I, Sheilah Nicholas, am anchored by birthright in my Hopi ancestral homelands, Tuuwanasavi, the Black Mesa region of the US Southwest. My language work has illuminated the path to (re)member myself to place and community so that I can share the "harvest" of 
my quest in reciprocity to my ancestors, my people, and those to come.

Welina me ke aloha. 'O au nō 'o Candace Kaleimamoowahinekapu Galla. As a Kanaka Hawai'i and associate professor, I have kuleana (responsibility, privilege) to serve my community back in Hawai' $i$, the diaspora, as well as other Indigenous communities, in our individual and collective effort of language reclamation, renewal, and restoration.

'Ano'ai e ka mea heluhelu è. 'O au nō 'o Keiki Kawai'ae'a no Keaukaha, Hawai'i o ka ua Kanilehua. Warm greetings all. I am Keiki Kawai'ae'a of Keaukaha, Hawai'i of the Kanilehua rain. I am a mother, grandmother, educator, and administrator striving to revitalize my beloved Hawaiian language as the "normal" language of home and daily life. I'm on a wonderful journey of rediscovery of my Hawaiian identity and returning Hawaiian to the home across multiple generations of my 'ohana (family) and kaiaulu (community).

aya, Wesley Leonard weenswiaani. niila myaamia. Hello, my name is Wesley Leonard. I am Miami. I was greatly influenced by my late grandfather, who believed in the future of the Miami people and in the reclamation of our once-sleeping language, myaamiaataweenki. I became a linguist to support these efforts and strive to build capacity for decolonial language work.

I, Wilson de Lima Silva, am originally from Manaus, Brazil. I am an assistant professor in the Department of Linguistics at the University of Arizona, where I direct the Master of Arts program in Native American Languages and Linguistics. I promote capacity-building 
workshops with Indigenous groups in Amazonia, thus seeking to contribute to language work that engages communitarian and social justice objectives.

\section{Introduction}

In Hopi storytelling, Spider Woman is a central figure. The spirit of Spider Woman represents all earthly knowledge. Spider Woman was instrumental in making the world habitable for humans. She is believed to be the driving force behind discovery and innovation. (Hartman Lomawaima in Ferrero, 1986, p. 4)

As Chikashsha, Hopisino, Kanaka Hawai'i, myaamia, and Brazilian scholars, we are engaged in Indigenous Language Revitalization (ILR) as a named and "growing field of community action as well as academic interest and involvement" (Hinton et al., 2018, p. xxi). Through this article, we come together to story our language work and journeys. We draw on the metaphor of a spider's web to convey the interconnectedness of our relationships to one another. Through sharing experiential narratives which privilege a cultural lens (Archibald, 2008), we story our Indigenous language work. We define "language work" as active, dynamic, in the present, and occurring within ILR.

From our positionalities and locations-communities and institutions-we ask and reflect on the following questions:

- Who are we storying with and for?

- What does language work look like in our community contexts and academic collaborations? 
- How do we define cultural praxis in our work? What principles inform and emerge from our collective work?

- How do we co-construct knowledge(s) that will sustain our language work and relationships?

We began our writing process with virtual meetings to create a space for us to come together on our own terms to collectively explore and engage the issues that matter to us and our language work. Google Docs became our shared writing space, with each author posting their story. We then engaged with one another's stories as a process of collaborative storying, reflecting Indigenous norms of co-produced knowledges that also illuminated interactions and intersections of our language work with and for Indigenous communities. This reflective and reflexive process originates from the deeply personal and particular, within the contexts of highly local and social ways of knowing and engages and maintains a continual balance of the cumulative past and present toward the future. Foremost, we aspire to act and work consistently in ways that are good for our peoples and communities. This includes a view of our language work and scholarship as purposeful journeying (Hill \& Wilkinson, 2014).

\section{Storying Our Language Work}

Through our storywork, we explore how Indigenous people who are reclaiming their ancestral languages and their co-resistors (Simpson, 2011) have entered academia with goals to advance and play a contributing role in community language reclamation efforts and broader resurgence movements. Representing diverse Indigenous communities—our own and those with and for whom we work-we come together in support of language 
reclamation within these communities and to affirm one another in this work.

We ground our storywork in a language reclamation framework "of claiming-or reclaiming - the appropriate cultural context and sense of value that the language would likely have always had if not for colonization" (Leonard, 2011, p. 141). By telling our stories individually and collectively, we engage in a "dialogic, intergenerational storying approach" that is "accessible and graceful, but also answerable and rigorous" (Tuck \& Yang, 2019, p. xi). We center community needs and perspectives, and, by extension, privilege communities' norms of sharing their needs and perspectives and transparency in our process that includes accountability to one another and to those who will hear our stories. We distinguish between listening and hearing and between language and voice. We challenge our audience to listen to our languages, AND to hear our authentic voices (Warner, 1999). We also invite readers into the conversation that we assert is not about us but ultimately for and led by us.

Notably, each of us does ILR work from positions within particular academic disciplines, such as Indigenous studies, education, and linguistics. Following Leonard (2018), we propose a distinction between named academic fields that are capitalized and uncapitalized areas of work and study. For example, Linguistics is a field concerned with the scientific study of language, including formal theories, while linguistics refers to a broader, humanistic approach to language. All of the authors work to Indigenize the disciplines to which we are connected. In some cases of our training, these disciplines have had established Indigenouscentered programs, like the summer AILDI. Nonetheless, we still find ourselves performing within disciplinary structures and "truths" that have often been harmful to our communities. 


\section{The Spider Web Conceptual Model}

Indigenous scholars Leola Roberta Rainbow Tsinnajinnie, Robin Starr Zape-tah-hol-ah Minthorn, and Tiffany S. Lee (2019) teach that "we each have a unique story to tell," and the "process of storying together reveal[s] where our pathways intersect" (p. 51). In searching for these intersections, we employ the metaphor of a spider's web. The web offers a conceptual and visual image of how we perceive and present ourselves as a community of scholar-educators engaged in Indigenous language work. The web structure captures our intuitive recognition that we comprise a dynamic, multi-sited, heteroglossic, and multivocal community that illuminates how our work is multifaceted yet intersected in the shared spaces of the web. Santa Clara Pueblo scholar Anya Enos (2017) describes the spider's web as both a metaphor, a visual display, and a demonstration of interconnectedness spanning history-Indigenous lives and experiences across time. The spider's web is a "microenvironment [capturing]—an individual ... or a snapshot of time in history," and at

other times, it is a "macroenvironment-[encompassing] worldwide Indigenous communities or time immemorial" (p. 43). The spider's web becomes an apt metaphor to articulate a response to our question: Who and what are we storying for?

\section{Microenvironments}

The web's microenvironment locates place or the community where we are undertaking our language work and within which our individual stories unfold. The following map (Figure 1) locates the primary sites of language work embedded in our stories. 


\section{Figure 1}

Locations of Our Language Work

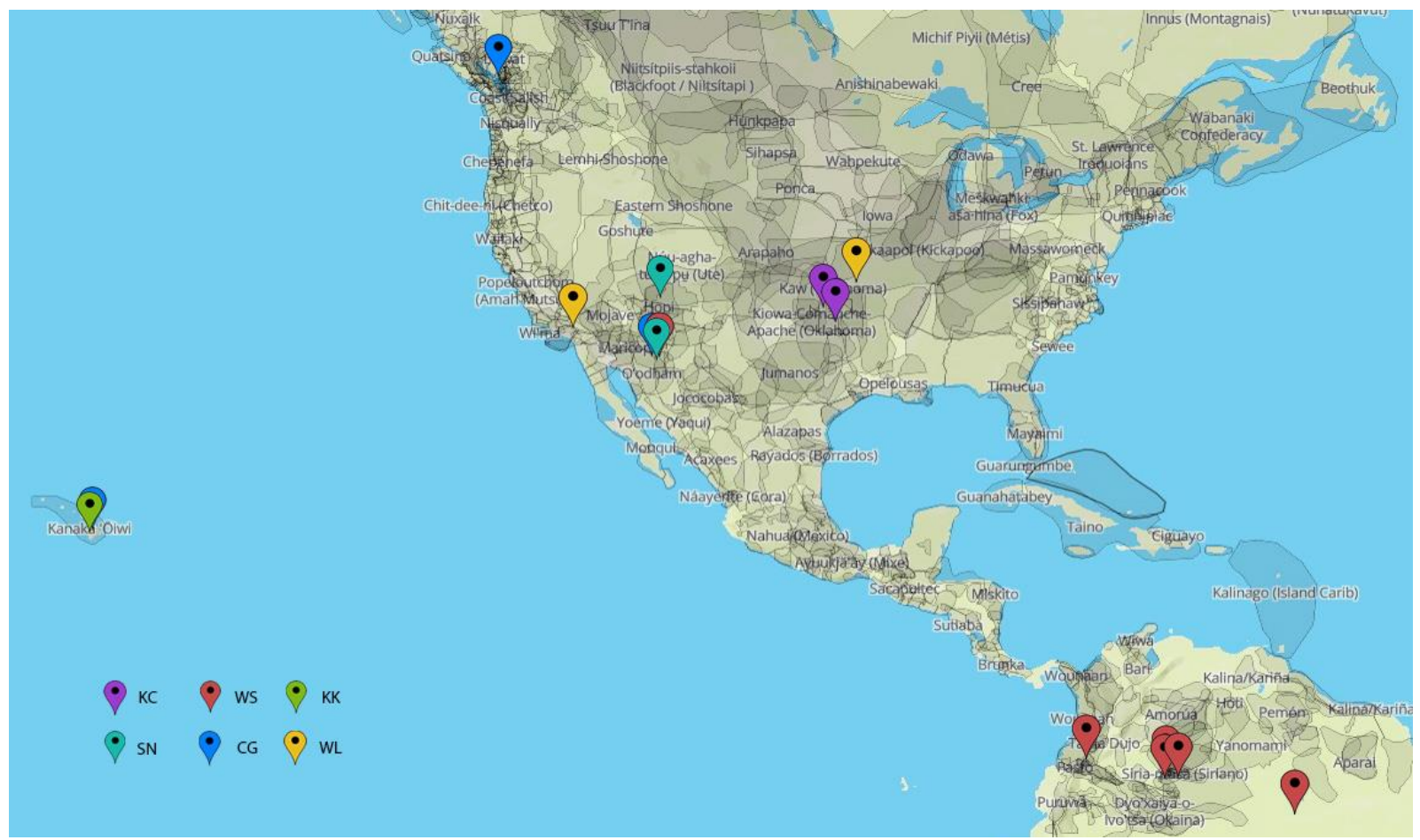

Note: Map of Indigenous territories from native-land.ca

\section{Macroenvironments}

The web is also a "macroenvironment" that encompasses the multiple communities in which our language work stories unfurl simultaneously. The metaphor allows us to see the multiplicity of our stories and thus voices as reverberating along the strands of the web in maintaining and sustaining the interconnectedness of Indigenous peoples across place and time. The web structure offers an approach to storying our respective language work that considers how our relationships and concepts are interrelated, shared, and used to inform, advance, and benefit community goals and efforts. Figure 2 below provides a visual overview of the diversity and complexity of current spaces of ongoing "language work." Such 
Indigenous spaces generate the stories that "speak for us" (Naranjo, 2017, p. 29, citing Ortiz, 1999) and work to inspire, encourage, and empower us as we engage in language work.

\section{Figure 2}

Points of Intersection: Indigenous Language Work

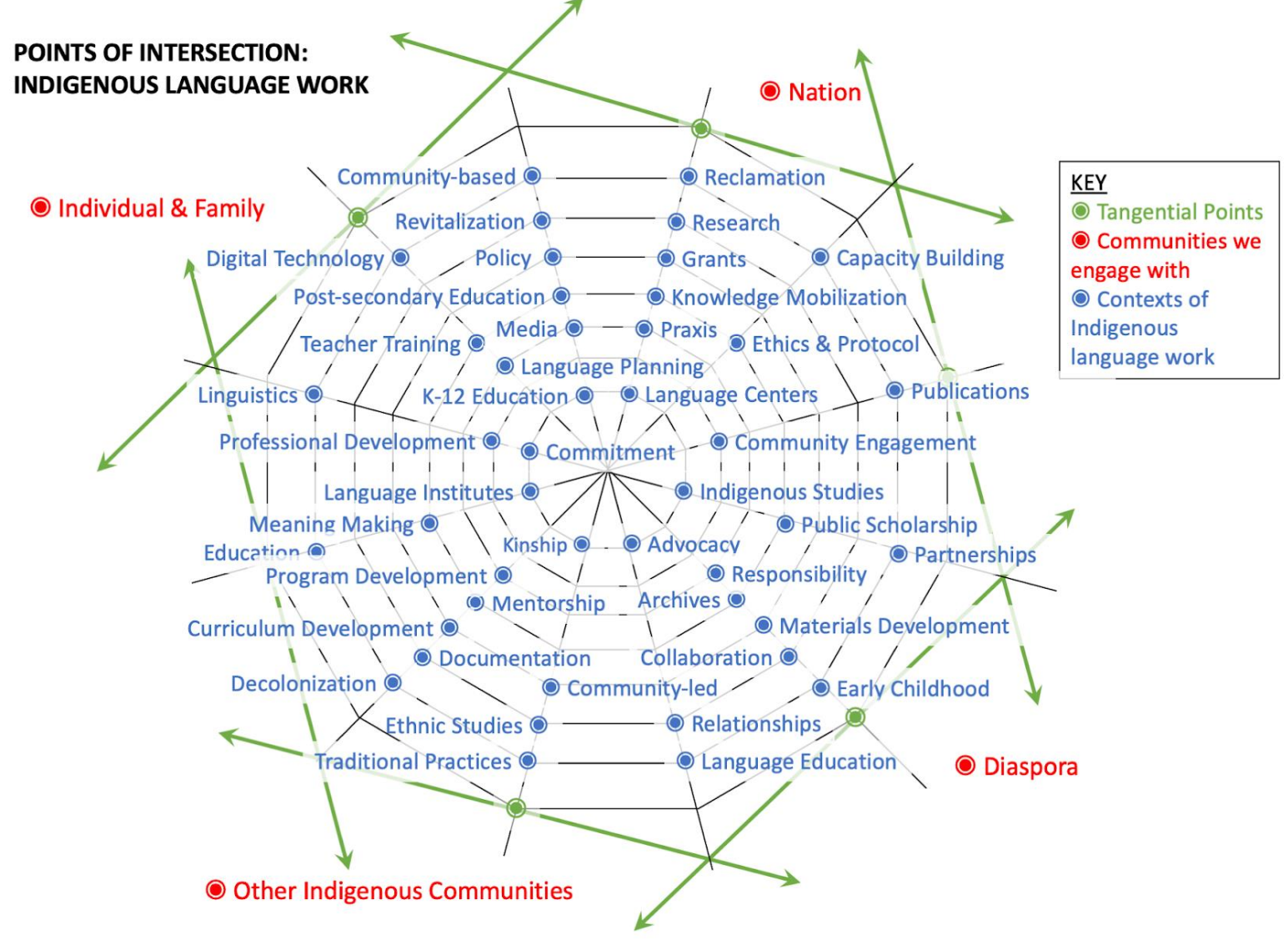

Note: Created by Candace K. Galla

\section{Tangential Points}

The efficacy of the spider web structure applies to storying our language work, as Indigenous academics, to illustrate how our stories "touch on others" outside the micro- and 
macroenvironments of Indigenous worlds and spaces. We draw on Deloria's concept of tangential points:

The best method of communicating Indian values is to find points at which issues appear to be related. Because tribal society is integrated toward a center and nonIndian society is oriented toward linear development, the process might be compared to describing a circle surrounded with tangent lines.... There are a great many points at which tangents occur, and they may be considered as windows through which [we] can glimpse each other. (Deloria, 1970, p. 12)

We use the image (see Figure 2, the green points of intersections and lines) to illustrate those points of interactions and intersections or windows through which our storying can be heard and our language work shared as well as better understood. The efficacy of the spider web metaphor is evident in the works of other Indigenous scholars (e.g., Archibald, 2008; Lambert, 2014; Maaka et al., 2018).

Figure 2 visually illuminates how our respective disciplines, communities, and approaches to language work span these multifaceted aspects of our language work to inextricably link, reflect, and display the diversity and complexity of ILR community efforts. We understand these as places of resurgence, as a collective act of resurgence, and Indigenous presence (Simpson, 2011). We view our personal storying and engaging with each other's stories as reinstituting "Indigenous processes" (p. 17) that compel us toward resurgence and to articulate our shared visions for renewing Indigenous futures. The process of collaborative storying reflects Indigenous norms of co-produced knowledges. As authors, we have begun to articulate these knowledges and understand that readers will find their own tangential 
points and develop the meanings in stories along with the original authors. The following sections present each author's story.

\section{Toompalli': Summer Will Come Again (Chew)}

The Chickasaw Nation uses the metaphor of the four seasons to tell the story of a Chikashsha renaissance-a rebirth following our forced Removal to Indian Territory beginning in 1837. Toompalli' (summer) is the beginning of the Chikashsha New Year. Within the metaphor, it represents the struggles of Assipóngni' (my ancestors) to rebuild their lives in an unfamiliar place. During this season, the deep connection between place and language was severed. Hashtola' ámmo'na' (fall), a time of transition, represents survival against an onslaught of colonizing and assimilatory US policies meant to eradicate Indigenous peoples. English-only schooling caused many chokka-chaffa' (families) to stop speaking or suppress the language. Hashtola' (winter) describes the keeping of faith, as okla (the people) carved spaces of cultural and linguistic continuity. The language had a space in aaittanaa' (churches), which were sites of political and cultural revival. Chikashsha okla flourished during toompalli' ishtayya' (spring) as the Chickasaw Nation found increased political and economic stability. During this season, the work of language reclamation became a priority for the Chickasaw Nation as a whole. In 2007, 170 years after our forced Removal from our homelands, the Nation founded the Chickasaw Language Revitalization Program.

My language learning journey began one year later, in 2008, when I participated in my first language class. Since that time, I have worked to increase my knowledge of pomanompa (our language) and to navigate higher education in ways that support my language work. While I 
have found supportive spaces to engage with my work, the academy has also resisted my presence. I recall the first academic conference I attended as a new doctoral student. I presented a story of how that 2008 language class changed my life because I learned to say Chikashsha saya (I am Chickasaw) in my ancestral language. Coming to say these words in Chikashshanompa' revealed to me my responsibility to continue learning the language and sharing it with other Chikashsha. After I presented this story, a colleague stated, "you speak so colloquially," noting that my English was more familiar than the formal and highly specialized language commonly used and expected in academia. This comment and similar ones compelled me to reflect on my speaking style and the way in which I presented myself as a Chikashsha scholar. I decided that I would strive to speak "colloquially," using Chikashshanompa' when possible and to my ability so that my words would feel familiar first and foremost to my ancestors, my community, my family, and other Indigenous persons actively engaged in the work of language reclamation.

Storying, using our authentic voices, is rigorous (Tuck \& Yang, 2019), and, because it is an act of resistance to the norms of academia, it is hard work. As a Chikashsha scholar reclaiming Chikashshanompa', my efforts to learn my language have required me to also learn the language of the academic disciplines which have held captive Chikashshanompa' linguistic knowledge. I spent nearly a decade as a student in higher education studying disciplines out of necessity in order to access my language. Once, I was particularly frustrated by this reality and expressed to another Chikashsha language advocate that I've spent the last decade reacting to the work of non-Indigenous researchers who have studied our language. Swinomish and Tulalip photographer Matika Wilbur, whose Project 562 
challenges stereotypical representations of Indigenous people, calls this narrative correction work (Wilbur \& Keene, 2020)—or the work of resisting the stories that oppress Indigenous peoples by portraying us and our languages as deficient, vanished, or conquered. The work beyond narrative correction is imagining Indigenous futures beyond settler colonialism (Wilbur \& Keene, 2020).

I story with and in relation to Chikashsha okla, as well as other ILR scholars and practitioners, to imagine and usher forth these futures where Indigenous languages flourish again. One form this storying takes is collaborative, community-based work to create our Rosetta Stone Chickasaw online language course. This course is significant because it represents the first time our community has come together to create a multi-year language curriculum with four levels comprised of a total of 160 one-hour language lessons (Hinson, 2019). This course reflects the input of Elder speakers, community members, and scholarpractitioners. As Chikashsha okla, we know that the seasons will continue to change and toompalli' will come again soon, bringing a new year and the beginning of a new chapter in the story of who we are as Chikashsha okla. As a result of individual and collective Chikashsha language work, I envision toompalli' as a time where the next generation of Chikashsha shaali' (language carriers or language learners) are not burdened by narrative correction work and have full access to their language as their birthright. Their stories will not be about learning to, and subsequently claiming the space, to say Chikashsha saya because they will know and they will already have this freedom. 


\section{Braiding the Strands of Language Reclamation Work (Nicholas)}

The northeastern plateau region of Arizona in the US Southwest remains as the historic and contemporary homelands of the Hopi people who speak Hopilavayi, a Uto-Aztecan language. The remoteness of the region has helped to preserve much of the culture in its traditional form but does not give immunity to the impact of colonizing processes manifest in sociocultural and sociolinguistic change that reverberates in the commentary: "If we don't work on this language issue, we'll be Hopi in name only. There will be no meaning beyond that." The truth of this perception was the first rude awakening to this personal reality in the context of my work in a foreign country when I responded with silence to the question, "What is a Hopi?"

Years later, as a graduate student at the AILDI at the University of Arizona, I would confront another rude awakening that merged my personal and academic trajectories on a course to "my true calling" - to attend to my ancestral language—through processes encapsulated in the Hopi concepts "naami yori" (taking a look [back] at myself) and "naamiq yori" (looking inward). The AILDI instructors, Hopi research anthropologist, the late Emory Sekaquaptewa, and linguist, Dr. Akira Yamamoto, each played a pivotal role. Emory opened the door to Hopilavayi literacy through which I understood the significance of being immersed from conception through childhood in my Hopi world through the language. On the other hand, immersion in the Western world through the English language and schooling served to dismember me from my Hopi world in a profound way. Dr. Yamamoto, through a course assignment, gave rise to vocalizing this reality when I asked, "Where did my language go?" Reassuringly, he explained that my language was not lost; rather, it had receded into the 
depths of my being waiting to be called forth—signaling the beginning of my language work at a personal level. My initial efforts to use Hopilavayi with my late mother prompted her response, "Um tsayniiqe paas Hopiningwu. (When you were a child, you were "fully" Hopi.)" and reiterated my shame of being Hopi in name only but would serve as the catalyst to (re)search the meaning of being fully Hopi.

Invited to assist Emory in providing monthly Hopi literacy instruction for Hopi students at the local high school, I was intrigued to learn that despite being raised in Hopi culture from birth, these Hopi youth had not acquired a Hopilavayi proficiency. The Hopi way of life based in the ancestral agricultural tradition and ceremonial rituals continue to be practiced in contemporary Hopi life; what was the current and would be the long-term impact? My dissertation research became the academic aspect of my language work-investigating the intergenerational interface of culture, language, education, and identity through case studies centering on three Hopi youth. The saliency of Hopi oral tradition and the traditional Hopi identity formation process, affective enculturation nurturing lifelong allegiance-Hopiqatsit aw unangvakiwyungwa (Having one's heart in the Hopi way of life) among contemporary Hopi youth despite language shift—or language as cultural practice (Nicholas, 2009), became fundamental to my ensuing language work in language teacher preparation.

The Hopi response (tribal mandates) has positioned schools as the primary sites of language revitalization. Tribal funding directed to Hopi language teacher professional development to assist school-based culture and language programs repositioned my language work with, for, and in my community in the design and implementation of the Hopilavayi Summer Institute 
2004-2010 (Nicholas, 2021). I brought a Hopilavayi literacy and receptive proficiency, a commitment to and background in the oral immersion approach to language teaching, and a long-term instructor and administrative experience with AILDI as a program model to foster a tribal-university-school partnership. This "preparation" aligned well with communitybased resources, aspirations, and needs. Respectively, Institute participants, paraprofessional, and certified teacher-speakers are critical resources who live the curriculum (the Hopi way of life) and continue the oral tradition, which remains vital in contemporary Hopi life. Learner aspirations were voiced as poignant yearnings to participate "fully" in Hopi life while a desire to re-instill the value of kyaptsi, respect for the Hopi way of life, resounded in the community. Respect, understood as emanating from an understanding of the core Hopi values implicit in cultural and linguistic practices, required these to be made explicit to the youth through "teaching" the language in formal spaces, an unprecedented need that was realized. I story for these first teachers of community youth who uphold traditional cultural praxis that speaks to right relationships, respect, cohesiveness, well-being, and survival-lomaqatsi, the good life.

\section{E Ho'omau: Indigenous Language Work at the Periphery of Academic Institutions} (Galla)

At the time of writing, I have lived over half of my life away from my traditional homelands of Hawai'i. As a guest and visitor to the homelands of the Tohono O'odham during my undergraduate and graduate studies at the University of Arizona in Tucson, and now to the

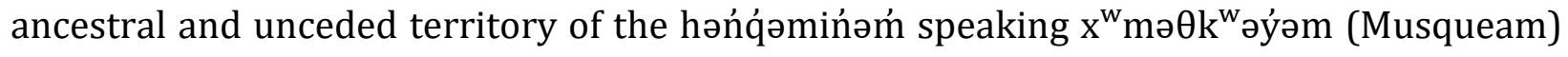
people as a faculty member at the University of British Columbia in Vancouver, I have been 
keenly aware of my positionality. I have had experiences of inclusion and exclusion within and outside the institutions. Notwithstanding, my story is not unique to me and may be familiar among my Indigenous colleagues and students in post-secondary institutions.

My path in academia was unclear for many years as I navigated a multitude of contexts in a Western institution. I meandered between majors hoping to find a discipline that would inspire yet challenge me and allow me to give back to my community. The summer leading into my fourth year as an undergraduate, I registered for a general education course about language. This course piqued my curiosity and set me on a path to major in Linguistics. I did not know where this degree would take me, but I knew that Linguistics provided me an opening to reconnect with my Hawaiian language while living away from Hawai'i. My growing interest prompted me to continue with graduate studies in the Native American Languages and Linguistics Master of Arts, with a focus on 'Ōlelo Hawai'i. My master's program began with two courses offered through the AILDI in 2004.

The AILDI was a novel space that allowed for critical discussions regarding language vitality to occur in the academy with Indigenous language speakers, learners, educators, policy makers, community members, and Allies from across Turtle Island and beyond. It was the place that humanized the discipline of linguistics for me and reignited my passion for my language and culture. I met colleagues and faculty from diverse communities, cultures, and linguistic backgrounds who became lifelong friends and mentors who shared stories of language loss, struggle, hope, and renewal with tears, laughter, and understanding. The AILDI privileged Indigenous knowledge systems-at a time when other academic 
departments and programs questioned, resisted, opposed, and/or silenced Indigenous ways of knowing-being. The AILDI became my "home"-an anchor point in the university where I learned from and with Indigenous faculty, staff, students, and community members-a stark juxtaposition from the rest of the institution.

That same year, a relational network of Indigenous doctoral students at the University of Arizona created the Indigenous Thinkers in response to the lack of Indigenous scholarship, research, curricula, pedagogies, methodologies, and representation in Indigenous education within the College of Education (Galla \& Holmes, 2020). This was an attempt to "make the academy both responsive and responsible to First Nations goals of self-determination and well-being" (Justice, 2004, p. 113). Indigenous Thinkers was a way for us as Indigenous and emerging scholars in the Western academy to establish a "continuous, visible, and active presence" (Mihesuah \& Wilson, 2004, p. 5) in the College of Education and at the University of Arizona. "Through [Indigenous Thinkers], we (re)defined the meaning of 'success' for ourselves and each other, holding on to the aspiration of a doctoral degree that would be useful and relevant" (Galla \& Holmes, 2020, p. 54)—a purposeful journey (Hill \& Wilkinson, 2014) that we engaged in to create an environment and outcome that we wanted to see for ourselves, our communities, and each other.

Graduating with my doctoral degree, however, did not completely confirm or validate my "belonging" in the academy as I sought to find a critical mass of Indigenous scholars while endeavoring to attain tenure. We are still a minority, but a growing one. As a faculty member who taught at Ka Haka 'Ula O Ke'elikōlani College at the University of Hawai'i at Hilo, and 
now at the University of British Columbia, I continue to cultivate my place in the university as a diasporic Kanaka Hawai'i and an Indigenous scholar-practitioner.

Working in the context of Truth and Reconciliation in Canada has made me even more responsive to community language priorities, especially at a time when there is a raising of consciousness across the country (and beyond) that calls for change and action in order to redress the legacy and impact of residential schools. My positionality has afforded me opportunities to work alongside Elders, teachers, language speakers, and learners in British Columbia and Hawai'i with the intention to develop language materials and curriculum, document language and literacy practices, and explore digital technologies and tools for language learning and teaching. With this privilege and honor comes responsibility I have to each community I serve that is based on respectful relationships.

As an Indigenous language and literacy educator, and Hawaiian language learner, I stand on the shoulders of Indigenous scholars that came before me with the commitment to continue, e ho'omau, their work of chiseling away (individually and collectively) at the institution to allow Indigenous knowledge systems, voices, and bodies to occupy more than a "space" in the academy that has attempted to eradicate our histories, lives, and communities. I story for Hawai'i, for Kanaka Hawai'i, for language learners and speakers, and for all Indigenous Thinkers and scholars so that we can envision a strong and brilliant Hawaiian and Indigenous future. 


\section{A Koe Nō Nā Pua: Shaping Our Destiny as the Vision Unfolds (Kawai'ae'a)}

In 1978, Hawaiian became an official language of the State of Hawai'i. At that time there were some 2,000 Native Hawaiian speakers, the last generation raised in Hawaiian speaking homes and communities (Kamanā, 2004). There were a handful of families, second language speakers like me, outside of the last Hawaiian speaking community of Ni'ihau, who were raising their children through Hawaiian as their first language through a pulakaumaka (a great desire to revitalize Hawaiian through a grassroots effort to renormalize our precious mother tongue beginning in the home).

That kuleana (responsibility and privilege) was ours to bear as children and grandchildren of the last native speakers of Hawaiian. We had a few thousand Elder speakers, Hawaiian language classes at the university, and some community programs, audio recordings, and an enormous repository of Hawaiian language written materials predominantly from the 19th century when Hawaiian was the national language to support our efforts.

For those handfuls of families who began, there was no sail plan in place and no great strategy to guide the way except a deep internal compass that was pointing in a new direction to ho'ōla i ka 'ōlelo (revitalize our mother tongue with our babies beginning in the home). Then in 1985, two Pūnana Leo preschools opened in Honolulu and Hilo. Then in 1987, the Department of Education opened the first public immersion schools in Waiau, O'ahu, and Keaukaha, Hawai'i. This afforded families like ours to bring our children together in a learning environment totally immersed through Hawaiian. E ola ka 'ōlelo Hawai'i (May the Hawaiian Language Live) was the simple vision to reclaim our native language. 
In the early years, many made personal and family sacrifices to establish new school sites, become teachers, prepare curriculum, and change law and policies at the state legislative level and Department of Education (Wilson \& Kamanā, 2001). With nearing 40 years of Hawaiian language revitalization efforts to reflect upon, the primary vehicle has been an educational platform to "maintain high standards of language, and cultural and academic excellence" (Kawai'ae'a et al., 2007, p. 186) through an educational pathway infant-toddler through PhD, a P-20 model.

From a frightening number of under 50 minor age (17 and younger) speakers of Hawaiian in the mid-1980s to the fifth non-English home language in the state, the 2000 US census reported 26,608 speakers of Hawaiian in the US (Ng-Osorio \& Ledward, 2011). On my home island of Hawai' i, 29.9 percent of the families speak Hawaiian in the home and Hawaiian is once again becoming a language heard in the community (Hawai'i State Data Center, 2016; State of Hawai'i, 2016). For example, here in Hilo, it's not unusual to hear Hawaiian being spoken in community places like the grocery store, community volleyball games, and at the beach by people I know and others I don't know.

Hawaiian medium (kaia'ōlelo) and Hawaiian-immersion (kaiapuni Hawai'i) schools are found in all four counties-Hawai'i, Maui-Moloka'i-Lāna'i, O'ahu, Kaua'i-Ni'ihau—as Department of Education and charter schools. There are currently 26 K-12 schools and 12 infant-toddler preschools with enrollment at about 3,700. The Commission on Language Learning (2017) reports that children in Hawaiian medium-immersion schools are 
graduating at a rate of three percent above the state average and are attending college at a rate of 15 percent above the Native Hawaiian average.

At the university level, Ka Haka 'Ula O Ke'elikōlani College at the University of Hawai'i - Hilo campus provides degree programs from bachelor to doctorate where Hawaiian is used as the language of instruction from upper-division undergraduate courses and above. In addition, general education courses are now available in Hawaiian for subjects like math, history, psychology, sociology, and Hawaiian language. Hawaiian medium teacher preparation is a full-track program offering certificates in early education and $\mathrm{K}-12$ as preservice preparation for licensure with masters and doctoral degrees for Indigenous education contexts. University of Hawai'i Mānoa, UH Maui College, UH West-O'ahu, and Brigham Young University-Hawai'i also have multiple programs strengthening Hawaiian language and Hawaiian knowledge opportunities that collectively are raising the bar in higher education.

It has been a powerful experience through the good times and challenges to reclaim a language that is highly endangered. It requires one to deal with personal internal struggles as second language speakers and the immense social pressure against mainstream English norms to stay the course with our children as the primary collateral. As a parent and now a grandparent of Hawaiian speaking children, there is unbelievable joy in hearing Hawaiian spoken again across three generations. It is part of our family strength and the legacy we have returned to our family history. 
After nearly 40 years of Hawaiian language revitalization work, I continue to hear people ask, "are your children succeeding in English?" The answer is yes, of course, and their lives have been enriched as speakers of Hawaiian. English is everywhere in our community, and the general public attitude towards English being the language of success continues to deter the efforts of revitalizing our language. Therefore, failure is not an option, and staying the course will continue to yield positive results for generations to come. Towards these efforts, Hawaiian is showing promising signs of language recovery.

The vision continues to be more than just a dream; it has been a trajectory explosion to recalibrate Hawaiian identity and "to bring life back to our mauli, our life spirit" (Kamanā, 2004, p. 150) grounded in our language, culture, and place for future generations. Our proactive stance has also been a healing process to reclaim our language as an inherited right for our families and communities: A legacy for future generations to build upon as new chapters of the story unfold for 'ōlelo Hawai'i (Hawaiian language) - a koe nō nā pua (only the flowers [descendants] remain). Towards a bright future that reclaims our mauli through our language, we must continue to hold the vision as a banner of victory, e ola ka 'ōlelo Hawai'i, e ola nā 'ōlelo 'ōiwi, e ola nā iwi (may the Hawaiian language live, may Indigenous languages live, may the bones of our ancestors live on).

\section{myaamiaatawiaanki kati: A Reclamation Narrative (Leonard)}

myaamiaki eemamwiciki (the Miami awakening) is a story about reclamation, and this is how many members of my tribe name the cultural renaissance and recovery of our language, myaamiaataweenki, from archival documentation. myaamiaki eemamwiciki describes how 
the Miami people came together-literally in spaces that we make into our own despite colonial invasion, and metaphorically in our shared vision of building a strong Miami future. It begins with our ancestors, who documented the knowledge needed for our awakening after a long period in which many Miami cultural practices were dormant. However, myaamiaki eemamwiciki is not an historical narrative or winter story, but rather a contemporary account that continues to develop as we reclaim our culture, language, and well-being. myaamiaki eemamwiciki emphasizes our outcomes of two forced Removals and how myaamionki (Miami place) thus includes not only the original homelands in Indiana and Ohio, but also the area of Kansas where my ancestors had a reservation in the 19th century after the first Removal, and the current seat of government in Oklahoma where Miamis came to live after the second Removal. It includes old accounts of how myaamia miincipi (Miami corn) came to the Miami people hundreds of years ago, and the more recent story of how cultivation of this unique variety of corn once stopped but came back into practice by planting seeds saved by an Elder, a process furthered by a collaborative ethnobotanical research project (Gonella et al., 2016).

Right from the start of my community's efforts to reclaim our language from documentation in the 1990s, which was also when the process began to be known as myaamiaki eemamwiciki, I think our intent was always to story with and for each other and to center Miami values. However, I realize now that we were initially unaware of the extent to which our language work was covertly being guided by others' ideologies, processes, and expectations. In particular, people kept saying that our language was extinct, so we had to go out of our way to justify that yes, it existed, and yes, we had the capacity to learn and speak 
it. Though part of this advocacy was directed inward toward community members who had internalized the idea of the "vanishing Indian," it was primarily a response to the colonial logics of Linguistics, which had adopted the damaging label "extinct" to describe myaamiaataweenki (Leonard, 2008). My current work aims to decolonize Linguistics, which offers useful tools for language reclamation but continues to other Indigenous scholars and language communities (Leonard, 2018).

Earlier actions within the story of myaamiaki eemamwiciki were also overly influenced by the idea that members of my community just needed to learn to speak myaamiaataweenki and that healing from colonial trauma would ensue. I did observe some healing, but there was a limitation in this thinking. The assumption might have been fine if we had been following more traditional notions of language, where relationships and interaction with people and places are so intertwined with myaamiaataweenki that "learning language" would accordingly be an embodied, relational process. However, I now realize that the initial efforts of my community overly drew on Western notions of language and language pedagogy. Even if ostensibly meant to support Indigenous communities, dominant approaches that frame languages as objects to be acquired easily further the colonial project by controlling how we, who are part of Indigenous communities, relate to our own languages. The programs we have developed more recently build Miami identity and center relationality in ways that respond to the ruptures that underlie my community's earlier shift away from myaamiaataweenki. For example, many of our educational programs take place outdoors, emphasizing interactions with earth and sky, and participants learn and use language in culturally grounded, interactional contexts. Tribal events are increasingly 
framed as gatherings of relatives with the phrase ceeki eeweemakiki (all my relations) now common along with niila myaamia (I am Miami) and kiiloona myaamiaki (we are Miamis). For us, language reclamation entails building and supporting relationships with each other, our ancestors, our non-human relations, and land.

Another type of relationship has also come to characterize Miami language work. Respectful collaboration within tribal-academic partnerships has become a hallmark of Miami cultural and language reclamation praxis (e.g., Baldwin et al., 2016; Baldwin \& Olds, 2007; Gonella et al., 2016; Leonard \& Haynes, 2010) and is guided by the belief that research facilitates reclamation provided that the people and institutions involved are respectful of Miami intellectual and political sovereignty. As with my efforts to reimagine Linguistics from an Indigenous lens, educating about Indigenous approaches to research is part of this praxis. neepwaantiinki (we learn from each other) has become a named concept to describe these partnerships, which reflects how the co-production of knowledge builds and sustains relationships. Responsibility, which aligns with respectful relationships, informs our practice of sharing the knowledge developed through these partnerships so others can benefit, though we are vigilant about the ongoing threat that knowledge can be misused. Because of this approach, there are many non-Miamis in the story of myaamiaki eemamwiciki, and my vision is that this story will continue to build reclamation capacity both for Miamis and for our co-resistors: myaamiaatawiaanki kati (We will speak myaamia). 


\section{From Theory to Practice and Back (Silva)}

I write with my current and former Native American Languages and Linguistics Master of Arts students in mind. The cohort of students in this program is diverse: Some are native speakers or second language learners of their Indigenous language, and a few are nonIndigenous students who work in collaboration with an Indigenous community. Students enroll in the program because they are interested in formal training in the kinds of skills needed to work on maintaining, revitalizing, and documenting their own language or the language of the community with which they work. Becoming a scholar with formal training in Linguistics was a kind of serendipitous thing that grew out of my work with a diasporic Tikuna community in Manaus, my hometown.

My involvement with Indigenous language preservation work began in 2001, as a volunteer with the Tikuna people in Manaus. At the time, I was an undergraduate student and invited to join a community-based project that focused on assisting two community members, Aldenor Félix and Tobias da Silva, who had just completed high school, in language pedagogy and language material development. Sadly, the community lost Aldenor Félix to COVID-19, and I dedicate this work to his memory. Due to concern that, once in the city, the children and young adults would lose interest in their language and culture, community leaders wanted to create a school in their newly established community in Manaus. I was studying English as a Foreign Language at The Federal University of Amazonas and was familiar with language teaching pedagogies. At the time I was not familiar with Linguistics, but this did not preclude us doing the work and achieving the goals of the community project. 
My work experience with the Tikuna community, combined with the formal training in Linguistics in graduate school, influences the projects I am currently undertaking with Indigenous communities in Brazil (Desano), Colombia (Desano, Siriano, Muteã), and Ecuador (A'ingae). My work focuses on methodologies that emerge from collaboration with members of the communities, and in tandem with their community goals. We adopt the research approach outlined by Dupris and Silva (forthcoming) in which language revitalization activities are center stage, and from which the activities of language documentation, training, and linguistic analysis derive. Figure 3 shows a formal representation of this model.

\section{Figure 3}

Knowledge Flow (Dupris \& Silva, forthcoming)

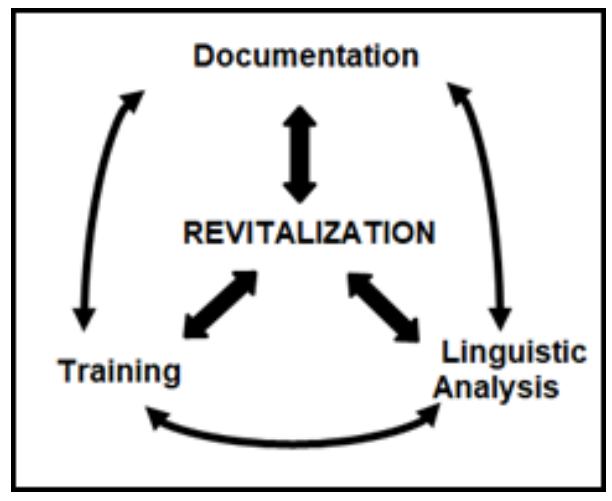

Because language revitalization is often led by the community, this model suggests that the other activities, that is, documentation, linguistic analysis, and training, coexist in the context of the community goals to revitalize their language. The model fosters a relationship in which stakeholders may explicitly address the skillsets they can bring to the project and to the community. This can be beneficial for the community to achieve their goals. Thus, products 
and outcomes for language revitalization are no longer framed as afterthoughts of the scholar as a way to "give something back" to the community.

To illustrate this model at work, the project of developing digital animations and storytelling materials for the Desano traditional tales (Silva, 2016) is instructive. This project centered on the community's interest in promoting traditional knowledge to new generations of speakers using digital media. The project involved training of community members (artists) in digital animation technologies; it involved documentation activities, for example, participants used tools for annotating audio and video-materials used for creating captions for animations; and because animations provide the visual representation of the events in a narrative, the activities gave rise to explanations from the part of fluent speakers of the semantics of complex grammatical structures in the language, thus providing fruitful materials for linguistic analysis.

The model we adopt allows for the implementation of the concepts in the Indigenous Research Paradigm of the Spider Conceptual Model (Lambert, 2014). Furthermore, it provides an environment that fosters relationships and collaboration. This in turn promotes the training of community members as "curators for the languages," insofar as they assume the responsibilities of researchers, language learners, and language teachers (Furbee \& Stanley, 2002, p. 115). Finally, the work also promotes "collaborative consultation" (Leonard \& Haynes, 2010, p. 269) for exchanging knowledge through language research work and for building long-term relationships based on principles of mutual benefit, reciprocity, respect, ethical engagement, and trust. 


\section{Making Meaning through a Web of Stories}

Enos's spider web metaphor as both microenvironment and macroenvironment captures the essence of "time" across our stories. The web is a snapshot of our time, now, in Indigenous history as the generation bearing the legacies of forced Removal, relocation, displacement, dismembering, and diaspora. It is also our moment in time that has captured us, both individually and collectively, in enacting a critical consciousness and reawakening in the resurgence process. The following sections discuss three key themes, or tangential points, that emerge from our collective storywork: building relational spaces for language work in academia, upholding responsibility and speaking with an authentic voice, and ushering forth renewal and resurgence.

\section{Building Relational Spaces for Language Work in Academia}

All authors have in common the experience of navigating academia in order to advance their language work. There is a shared struggle in trying to locate our community-responsive language work within existing academic disciplines. Notably, we initially came together as a group in response to an invitation by the American Association for Applied Linguistics, which reflects a common assumption that language work belongs in Linguistics and related disciplines. For several of us, Linguistics was what Galla describes as an opening to reconnect to language. The siloing of Indigenous language work within academic disciples leads to challenges for ILR scholars, including feeling isolated and needing to constantly explain and defend anything Indigenous-related. Established programs and institutes like AILDI have been significant to breaking down disciplinary silos and creating transdisciplinary spaces within institutions for language work. Leonard describes this as making spaces our own 
despite colonial invasion. Within academia, these are spaces where generations of scholarpractitioners engaged in language work have chiseled away at the institution to not just occupy a space, but purposefully carve something that fundamentally changes the nature of the institution for everyone.

Notably, our group of authors represents multiple generations within ILR work. Those who are "younger" generations of scholars were invited into a supportive network. As Chew reflected in dialogue with other authors, "I am fortunate that, as an emerging Chikashsha scholar in ILR, I was brought into and mentored by a close-knit network of other scholarsseveral of whom are co-authors of this article-working to ensure the continuance of Indigenous languages. These mentors encouraged me to tell my story and created space for my story alongside theirs." Leonard further offered in conversation with co-authors that knowledge is co-constructed in these networks rather than in disciplinary silos: "I now see more clearly how much my reclamation praxis draws from networks that go far beyond my tribal community, especially important being those with other Indigenous scholarpractitioners. Reading my co-resistors' stories, even the parts that relate bad experiences, is ultimately a nurturing experience that reminds me of how colonizers keep trying to dismantle our Indigenous nations politically and ontologically—but they don't succeed because we're telling our own stories and building positive futures."

\section{Upholding Responsibility and Speaking With an Authentic Voice}

During collective reflection, Kawai'ae'a offered a quote printed in an old 1917 Hawaiian newspaper called Ka Puиhonua o na Hawaii: “'Ike 'ia nō ke kanaka no kekahi lāhui ma kāna 
'ōlelo" (a person is recognized where they are from by the language that is spoken) ('Olelo Hawaii'). Kawai'ae'a went on to say that "the reclamation of one's language is personal and a family and community commitment. It is a kuleana (responsibility and privilege) of urgent proportions and immense social pressures for Indigenous languages against mainstream norms." These words express a shared sentiment that language work is about upholding an urgent responsibility to oneself, family, and community. Upholding this responsibility requires one to be recognizable, through language and connection to place, to others. We understand this as speaking with an authentic voice and being in relationship with our languages. We become familiar with our languages and then use them in a familiar way so that our ancestors, community, family, and Indigenous colleagues can story with us. This is a means to provide well-being while also disrupting the (dangerous colonial) hierarchies of academia.

Our Indigenous languages express our authentic voices (Warner, 1999), and, as our stories demonstrate, dominant languages can also be claimed and used in ways that align with Indigenous values and further our ability to uphold responsibility to Indigenous communities. Chew's story of speaking in a way perceived to be too colloquial for an academic presentation prompted other authors to share similar stories. Silva was reminded of a decision to write a collaborative paper with Desano in the Amazonian Portuguese variety familiar to all the authors: "A reviewer wrote their review in English correcting my Portuguese and pointing out that the paper wasn't really an academic paper. The editors asked me to revise but I told them I wanted to keep the 'non-academic' voice. They published it!" Similarly, Leonard shared a story of being a special editor for a Linguistics journal and 
navigating tension between an Indigenous author and the main editors of the journal: "The main editors raised objections about the paper because of the style of writing. The author commented that the editors were trying to erase their voice as an Indigenous person." Like Silva, the Indigenous author ultimately published the piece, which is now cited and taught in university courses. Returning to Kawai'ae'a's words, we understand that we have a responsibility and privilege to honor our identities and the identities of others. In doing so, we not only celebrate our languages, but contribute to the efforts already begun of building relational spaces for language work in academia.

\section{Ushering Forth Renewal and Resurgence}

All of our communities are engaged in a cycle of renewal or rebirth. Thus, our language work requires both envisioning the future and keeping the spirit. By finding strength in our authentic voices, we are raising our critical Indigenous consciousness (Lee, 2009). For example, Chew "learned to say Chikashsha saya (I am Chickasaw)," words in her ancestral language that revealed a responsibility to continue learning the language and sharing it with other Chikashsha. Similarly, Nicholas found that she would only need to call forth her language that resided deep within. In these ways, we are guided by the footprints of knowledges from time immemorial that our ancestors left for us to find our way back to our authentic selves and that compel us toward resurgence. A raised consciousness enables us to free our minds to imagine and envision Indigenous linguistic futures and to cut the shackles of colonization (Kirkness, 1998). Drawing on the four Bs shared by kupuna Betty Kawohiokalani Ellis-Jenkins, who has been described as "a web-maker and grand spider for many people" (Calizar, 2012, para. 3), Kawai'ae'a reflected to the group: "Reclaiming one's 
language requires that one 'believe, behave, become, and belong' to the vision and stand vigilantly on course by raising one's language as a shining beacon of hope and guidance." In doing so, we claim our birthright for ourselves and for those yet to come.

\section{Epilogue}

Like Spider Woman, storying our language work has engaged us as co-authors in a collective process of connecting the multiplex strands of community linguistic histories and legacies and to the creation of a visual web of interconnectedness across the micro- and macroenvironments of our work. The spider web metaphor demonstrates how our language work, while multifaceted, multidimensional, and occurring across myriad locations, is an active and dynamic movement in the present, sensed through the concurrent reverberations of and across the multiplex strands. The spider web also elucidates the resiliency and persistence of an incessant movement undertaken since time immemorial forwarding positive Indigenous futures and presence- "that looking into [and to] the past is a part of looking forward and that our stories, like time, is not really linear" (Enos, 2017, p. 41). And, as Enos further notes, "the spider creates and modifies her web in response to the environment and need" (p. 42), assurance that our language work will continue to respond and unfold accordingly.

We have shared our stories amidst concurrently occurring traumatic events-a pandemic, natural disasters, social unrest, and contemporary economic crisis. The Hopi word, koyaanisqatsi, "life/the world out of balance," being uttered and heard again, is testament that these events are not unprecedented as reiterated in the Hopi prophecy; humankind has 
played a profound role in the recurrences. Still, Indigenous presence is also testament of survival, rebirth, and resurgence; thus, our coming together to story our language work is not only timely but a mobilization of a collective resurgence that we have embraced as our responsibility to enact in our time of Indigenous history. We all carry a responsibility for restoring balance and harmony. Michi Saagiig Nishnaabeg writer Leanne Betasamosake Simpson writes that "desired outcomes are heavily influenced by the processes we engage in, our relationships [with humans and non-humans], and how we live in this world" (2011, p. 144). In the spirit of Spider Woman and with discovery and innovation as the driving forces, we extend an invitation to reset the course toward rebirth. 


\section{Glossary}

\begin{tabular}{|l|l|}
\hline Indigenous Peoples \\
\hline Chikashsha & Chickasaw \\
\hline Hopisino & Hopi \\
\hline Kanaka Hawai'i & Native Hawaiian \\
\hline myaamia & Miami \\
\hline Tikuna & community in Manaus \\
\hline
\end{tabular}

\begin{tabular}{|l|l|}
\hline Indigenous Languages & \multicolumn{2}{|l|}{} \\
\hline A'ingae $^{\prime}$ & $\begin{array}{l}\text { spoken by A'i in Ecuador and Columbia (also called } \\
\text { Cofán or Kofán) }\end{array}$ \\
\hline Chikashshanompa' & Chickasaw language \\
\hline sposano & Hopi by Desano in Colombia and Brazil \\
\hline Hopilavayi & $\begin{array}{l}\text { Indigenous language spoken in Columbia (also called } \\
\text { Karapana) }\end{array}$ \\
\hline Muteã & Miami language \\
\hline myaamiaataweenki & Hawaiian language \\
\hline 'ōlelo Hawai'i & spoken by Siriano by in Columbia \\
\hline Siriano &
\end{tabular}

\begin{tabular}{|l|l|}
\hline \multicolumn{2}{|l|}{ Indigenous Language Organizations } \\
\hline $\begin{array}{l}\text { American Indian Language } \\
\text { Development Institute (AILDI) }\end{array}$ & $\begin{array}{l}\text { summer institute for language learners, teachers, and } \\
\text { speakers held annually at the University of Arizona }\end{array}$ \\
\hline $\begin{array}{l}\text { Chickasaw Language } \\
\text { Revitalization Program }\end{array}$ & $\begin{array}{l}\text { Chickasaw Nation program focused on ensuring the } \\
\text { continuance of the Chickasaw language }\end{array}$ \\
\hline Hopilavayi Summer Institute & $\begin{array}{l}\text { summer institute on Hopi community focused on } \\
\text { Hopilavayi literacy and language revitalization work } \\
(2004-2010)\end{array}$ \\
\hline Ka Haka 'Ula O Ke'elikōlani & $\begin{array}{l}\text { College of Hawaiian Language at the University of } \\
\text { Hawai'i at Hilo }\end{array}$ \\
\hline Natives4Linguistics & $\begin{array}{l}\text { a special interest group of the Linguistic Society of } \\
\text { America }\end{array}$ \\
\hline
\end{tabular}




\section{About the Authors}

Kari A. B. Chew is a citizen of the Chickasaw Nation, Chikashshanompa' (Chickasaw language) learner, and Indigenous language advocate. She is an assistant professor of Indigenous Education in the department of Educational Leadership and Policy Studies at the University of Oklahoma. Her research focuses on adult Indigenous language learners, Indigenous language curriculum, and the role of technology in Indigenous language education.

Sheilah E. Nicholas is a member of the Hopi Tribe and professor in the Department of Teaching, Learning \& Sociocultural Studies at the University of Arizona. Her research focus is Hopi language reclamation and Indigenous language teacher education. She is a Co-PI of a national study investigating Indigenous language immersion as an instructional innovation and its potential to benefit a wider population of Native students.

Candace K. Galla is Kanaka Hawai'i from Hawai'i Island and an associate professor in the department of Language and Literacy Education (Faculty of Education) and the Institute for Critical Indigenous Studies (Faculty of Arts) at the University of British Columbia. Dr. Galla's research focuses on Indigenous language learning through digital and emerging technologies, embodied language practices, and materials development.

Keiki Kawai'ae' $a$ is the Director of Ka Haka 'Ula o Ke'elikōlani College of Hawaiian Language at the University of Hawai'i at Hilo. Dr. Kawai'ae'a has played a pioneering and proactive role in the development of Hawaiian medium programs/schools, teacher education, curriculum development and the Ulukau digital library to reestablish and renormalize Hawaiian medium education P-25 (cradle-college-work-community).

Wesley Y. Leonard is a citizen of the Miami Tribe of Oklahoma and an associate professor of Ethnic Studies at the University of California, Riverside. Supported by a PhD in Linguistics and years of language work in his own tribe, Dr. Leonard's research focuses on building capacity for Indigenous language reclamation.

Wilson de Lima Silva is an assistant professor in the Department of Linguistics at the University of Arizona. He is the director of the MA Program in Native American Languages \& Linguistics (NAMA). Dr. de Lima Silva conducts research in the Desano and Siriano (two Tukanoan languages spoken in the Vaupés Region of Brazil and Colombia). Dr. de Lima Silva is engaged in exploring methodologies for language documentation and revitalization, including the training of students and community members in language research activities. 


\section{References}

Archibald, J. A. (2008). Indigenous storywork: Educating the heart, mind, body, and spirit. UBC Press.

Baldwin, D., Costa, D., \& Troy, D. (2016). Myaamiaataweenki eekincikoonihkiinki eeyoonkiaapisaataweenki: A Miami language digital tool for language reclamation. Language Documentation \& Conservation, 10, 394-410. http://hdl.handle.net/10125/24713

Baldwin, D., \& Olds, J. 2007. Miami Indian language \& cultural research at Miami University. In D. M. Cobb \& L. Fowler (Eds.), Beyond red power: American Indian politics \& activism since 1900 (pp. 280-290). School for Advanced Research Press.

Calizar, M. (2012). Ke ala a ke ku'uku'u: "Path of the spider" [Blog post]. Makua o'o. http://makuaoo.blogspot.com/2012/09/ke-ala-ke-kuukuu-path-of-spider.html

Commission on Language Learning. (2017). Developing heritage languages and revitalizing Native American language. America's languages: Investing in language education for the 21st century (pp. 22-26). https://www.amacad.org/sites/default/files/publication/downloads/Commissionon-Language-Learning Americas-Languages.pdf

Deloria, V., Jr. (1970). We talk, you listen: New tribes, new turf (Bison Books edition). University of Nebraska Press.

Dupris, J., \& Silva, W. D. L. (forthcoming). Sobre uma metodologia de documentação baseada nas atividades de (re)vitalização: Um estudo de caso. Cadernos de Linguística. ABRALIN.

Enos, A. D. (2017). With respect. ... In E. S. Huaman \& B. M. J. Brayboy (Eds.), Indigenous innovations in higher education: Local knowledge and critical research (pp. 41-57). Sense Publishers.

Ferrero, P. (1986). Hopi: Songs of the fourth world. A resource handbook. Arizona Humanities Council in cooperation with The National Endowment for the Humanities; Ferrero Films, National Endowment for the Arts Folk Art, L. J. Skaggs and Mary C. Skaggs Foundation.

Furbee, N. L., \& Stanley, L. A. (2002). A collaborative model for preparing Indigenous curators of a heritage language. International Journal of the Sociology of Language, $154,113-128$.

Galla, C. K., \& Holmes, A. (2020). Indigenous thinkers: Decolonizing and transforming the academy through Indigenous relationality. In S. Cote-Meek \& T. Moeke-Pickering 
(Eds.), Decolonizing and Indigenizing education in Canada (pp. 51-71). Canadian Scholars.

Gonella, M. P., Baldwin, D. W., \& Greenberg, A. M. (2016). Community-led ethnobotanical triage: Case study-Myaamia corn traditions. Ethnobotany Research \& Applications, 14, 517-531. http://dx.doi.org/10.17348/era.14.0.517-531

Hawai'i State Data Center. (2016). Detailed languages spoken at home in the state of Hawai'i. https://files.hawaii.gov/dbedt/census/acs/Report/Detailed Language March2016. pdf

Hill, G., \& Wilkinson, A. (2014). INDIGEGOGY: A transformative Indigenous educational process. Canadian Social Work Review, 31(2), 175-193.

Hinson, J. D. (Lokosh). (2019). Nanna ittonchololi' ilaliichi (We are cultivating new growth): Twenty years in Chikashshanompa' revitalization. [Doctoral dissertation, University of Oklahoma]. ShareOK. https://hdl.handle.net/11244/323267

Hinton, L., Huss, L., \& Roche, G. (Eds.). (2018). The Routledge handbook of language revitalization. Routledge.

Justice, D. H. (2004). Seeing (and reading) red: Indian outlaws in the ivory tower. In D. A. Mihesuah \& A. C. Wilson (Eds.), Indigenizing the academy: Transforming scholarship and empowering communities (pp. 100-123). University of Nebraska Press.

Kamanā, K. (2004). Reflections and feeling deriving from a pulakaumaka within my heart. In S. Greymorning (Ed.), A will to survive: Indigenous essays on the politics of culture, language, and identity (pp. 200-211). McGraw-Hill.

Kawai'ae'a, K. C., Housman, A. K, \& Alencastre, M. (2007). Pū'ā i ka 'ōlelo, ola ka 'ohana: Three generations of Hawaiian language revitalization. Hūlili: Multidisciplinary Research on Hawaiian Well-Being, 4(1), 183-237. http://www.kamehamehapublishing.org/hulili 4/

Kirkness, V. J. (1998). Our peoples' education: Cut the shackles; cut the crap; cut the mustard. Canadian Journal of Native Education, 22(1), 10-15.

Lambert, L. (2014). Research for Indigenous survival: Indigenous research methodologies in the behavioral sciences. Salish Kootenai College Press.

Lee, T. S. (2009). Language, identity, and power: Navajo and Pueblo young adults' perspectives and experiences with competing language ideologies. Journal of Language, Identity, and Education, 8(5), 307-320.

Leonard, W. Y. (2008). When is an "extinct language" not extinct?: Miami, a formerly sleeping language. In K. A. King, N. Schilling-Estes, J. J. Lou, L. Fogle, \& B. Soukup 
(Eds.), Sustaining linguistic diversity: Endangered and minority languages and language varieties (pp. 23-33). Georgetown University Press.

Leonard, W. Y. (2011). Challenging "extinction" through modern Miami language practices. American Indian Culture and Research Journal, 35(2), 135-160.

Leonard, W. Y. (2018, January 6). Toward a Native American linguistics. [Paper presentation]. 92 ${ }^{\text {nd }}$ Annual Meeting of the Linguistic Society of America. Special Session: Sharing Our Views; Native Americans Speak About Language and Linguistics. Salt Lake City, UT.

Leonard, W. Y., \& Haynes, E. (2010). Making "collaboration" collaborative: An examination of perspectives that frame linguistic field research. Language Documentation \& Conservation, 4, 268-293. http://hdl.handle.net/10125/4482

Maaka, M. J., Wong, K. L., Perry, W. K., \& Johnston, P. M. G. (2018). Indigenous leadership: A complex consideration. In E. A. McKinley \& L. T. Smith (Eds.), Handbook of Indigenous education (pp. 229-248). Springer.

Mihesuah, D. A., \& Wilson, A. C. (2004). Introduction. In D. A. Mihesuah \& A. C. Wilson (Eds.), Indigenizing the academy: Transforming scholarship and empowering communities (pp. 1-15). University of Nebraska Press.

Naranjo T. (2017). Stories of place and intergenerational learning. In E. S. Huaman \& B. M. J. Brayboy (Eds.), Indigenous innovations in higher education: Local knowledge and critical research (pp. 21-39). Sense Publishers.

Ng-Osorio, J., \& Ledward, B. C. (2011). Aia ke ola i ka 'ōlelo Hawai'i: Revival of the Hawaiian language. Kamehameha Schools-Research \& Evaluation.

Nicholas, S. E. (2009). “I live Hopi, I just don't speak it."-The critical intersection of language, culture, and identity in the contemporary lives of Hopi youth. Journal of Language, Identity and Education, 8(5), 321-334.

Nicholas, S. E. (2021). The Hopilavayi Summer Institute: A Tribal model of assistance for ancestral language teacher preparation. In L. Crowshoe, I. Genee, M. Peddle, J. Smith, \& C. Snoek (Eds.), Sustaining Indigenous languages: Connecting communities, teachers, and scholars (pp. 89-106). Northern Arizona University.

'Olelo Hawaii.' (1917, Ianuari 17). Ka Puuhonua o na Hawaii (Buke IV, Helu 4).

Ortiz, S. J. (1999). Men on the moon: Collected short stories. University of Arizona Press.

Silva, W. D. L. (2016). Animating traditional Amazonian storytelling: New methods and lessons from the field. Language Documentation \& Conservation, 10, 480-496. http://hdl.handle.net/10125/24703 
Simpson, L. B. (2011). Dancing on our Turtle's back: Stories of Nishnaabeg re-creation, resurgence and a new emergence. Arbeiter Ring Books.

State of Hawai'i. (2016). Non-English speaking population in Hawai'i. https://files.hawaii.gov/dbedt/economic/data reports/Non English Speaking Pop ulation in Hawaii April 2016.pdf

Tsinnajinnie, L. R. R., Minthorn, R. S. Z., \& Lee, T. S. (2019). K'é and Tdayp-tday-gaw: Embodying Indigenous relationality in research methods. In S. Windchief \& T. San Pedro (Eds.), Applying Indigenous research methods: Storying with peoples and communities (pp. 37-54). Routledge.

Tuck, E., \& Yang, W. K. (2019). Series editor introduction. In S. Windchief \& T. San Pedro (Eds.), Applying Indigenous research methods: Storying with peoples and communities (pp. x-xiii). Routledge.

Warner, S. L. N. (1999). Kuleana: The right, responsibility, and authority of Indigenous peoples to speak and make decisions for themselves in language and culture revitalization. Anthropology \& Education Quarterly, 30(1), 68-93. https://www.jstor.org/stable/3195982

Wilbur, M., \& Keene, A. (Producers). (2020, August 19). All my relations [audio podcast]. https://www.allmyrelationspodcast.com

Wilson, W. H., \& Kamanā, K. (2001). "Mai loko mai o ka 'i'ini: Proceeding from a dream": The 'Aha Pūnana Leo connection in Hawaiian language revitalization. In L. Hinton \& K. Hale (Eds.), The green book of language revitalization in practice (pp. 147-176). Academic Press. 